\title{
A scientific note on the association of Haptoncus luteolus (Coleoptera: Nitidulidae) with colonies of multiple stingless bee species
}

\author{
Kumara T. Krishnan ${ }^{1}$, Peter Neumann ${ }^{2}$, Abu Hassan Ahmad ${ }^{3}$, Marcela Pimid ${ }^{3}$ \\ ${ }^{1}$ Faculty of Agro Based Industry, Universiti Malaysia Kelantan, Jeli Campus, 17600, Jeli, Kelantan, Malaysia \\ ${ }^{2}$ Institute of Bee Health, Vetsuisse Faculty, University of Bern, Bremgartenstr. 109a, 3001, Bern, Switzerland \\ ${ }^{3}$ School of Biological Sciences, Universiti Sains Malaysia, 11800 Minden, Penang, Malaysia
}

Received 7 May 2014 - Revised 11 July 2014 - Accepted 28 July 2014

\section{Haptoncus luteolus / stingless bee / Trigona thoracica / parasite}

Different Nitidulid beetles can be found in social bee colonies (Ellis et al. 2008) and may range from harmless associates (e.g., Cychramus luteus, Neumann and Ritter 2004) to damaging parasites (e.g., Aethina tumida, Neumann and Elzen 2004). Haptoncus luteolus (Coleoptera: Nitidulidae, Figure 1a, b) is a fruit pest (Yunus and Ho 1980; Audisio et al. 1990) and has been reported as an associate of honeybee, Apis mellifera, colonies (Atkinson and Ellis 2011a, b). Here, we report for the first time its association with colonies of multiple stingless bee species.

In July 2013, beetle larvae $(N=6)$ were manually collected using entomological forceps from a thriving colony of the local stingless bee Trigona thoracica in Kelantan, Malaysia. The larvae were only found near and in multiple-punctured pollen pots in a bottom corner (Figure 1c). The pollen pots looked distorted oval and collapsed, which contrasts to the normal elongated oval shape in this stingless bee species (Michener 2013). No adult beetles were observed.

In December 2013, adult beetles $(N=21)$ were manually collected using entomological forceps from a thriving Heterotrigona itama, another local stingless bee. These beetles were hiding in the corners or under the brood comb of the colony. No beetle larvae was found.

Corresponding author: K. Krishnan,

kumara_k2001@yahoo.com

Manuscript editor: James Nieh
In January 2014, adult beetles $(N>100)$, larvae $(>100)$, and pupae $(N>100)$ were manually collected using entomological forceps from the colony of a different local stingless bee, Tetragonula laeviceps. Several brood, honey, and pollen pots were infested by the larvae and adults (see Michener 2013 for respective details on the nesting biology of stingless bees). Interestingly, we observed distinct bulges on the surface of the nesting material. Careful dissections revealed that those apparently served as pupation sites (Figure 1d). This heavily infested T. laeviceps colony collapsed.

All beetle samples were transported to the Biology Laboratory, Universiti Malaysia Kelantan. The adults were identified as H. luteolus (Coleoptera: Nitidulidae) [synonym-Epuraea luteola] based on definitive morphological characteristics (see Gillogly 1982; Figure 1a). Then, a successful standard laboratoryrearing program for small hive beetles was established using plastic containers $[18 \times 12 \times 6 \mathrm{~cm}$, with a pin-holed lid $(\varnothing=\sim 1 \mathrm{~mm})$, allowing for sufficient air circulation] and a diet consisting of pollen/honey/protein powder (Nutrilite ${ }^{\circledR}$, Amway) in a 1:1:2 volume ratio (Neumann et al. 2013), thereby confirming that H. luteolus is able to successfully reproduce on bee products.

Our observations show that $H$. luteolus can be associated with colonies of at least three different species of stingless bees. Taken together with earlier reports in honeybee, A. mellifera, colonies (Atkinson and Ellis 2011a, b), this suggests that this beetle species can exploit a variety of different social bee species. This is similar to the small hive beetle, which can infest colonies of honeybees (Neumann and Elzen 2004), bumblebees Bombus impatiens (Spiewok and Neumann 2006), 



Figure 1 Beetle life stages and clinical signs of infestation: a adult $H$. luteolus, b $H$. luteolus larvae, c damaged pollen pots of T. thoracica (white arrows), and $\mathbf{d} H$. luteolus larvae boring into the nesting material for pupation (white arrow) and pupation bulges (black arrows).

as well as stingless bees Trigona carbonaria (Greco et al. 2010) and Austroplebeia australis (Halcroft et al. 2011).

The present study also suggests that $H$. luteolus can complete an entire life cycle in association with stingless bee colonies while feeding on pollen and pupating in nesting material. While some beetles only seek shelter and/or food in social bee colonies (e.g. C. luteus in A. mellifera, Neumann and Ritter 2004), others also reproduce in the colonies (e.g. Cryptophagus hexagonalis in A. mellifera, Haddad et al. 2008). However, all of these beetle species have not been reported to pupate in the host colonies. Therefore, H. luteolus represents a novel degree of beetle association with social bee colonies (see Ellis et al. 2008) because it apparently can pupate within colonies, thereby separating this species from the previously reported cases.

Our observations further indicate that heavy infestations with this beetle can cause colony collapse in T. laeviceps . Even though this was a single observation only, it nevertheless suggests that heavily infested colonies of this and other stingless bee species and maybe even of honeybees may be damaged. We therefore raise caution that $H$. luteolus may cause damage to the Meliponini industry as well as colonies of wild and other managed bees. This creates demand for more studies on this beetle species ranging from the basic life cycle over behavioral host-parasite interactions to possible control measures.

\section{ACKNOWLEDGMENTS}

We wish to thank Mr. Zahari and Ms. Farisya for their kind field assistance. Financial support was granted by the Ministry of Education of Malaysia [R/RACE/A07.00/00760A/003/2014/000155] and by the Vinetum foundation [to Peter Neumann].

OPEN ACCESS This article is distributed under the terms of the Creative Commons Attribution License which permits any use, distribution, and reproduction in any medium, provided the original author(s) and the source are credited.

Une note scientifique sur l'association d' Haptoncus luteolus (Coleoptera: Nitidulidae) avec des colonies de diverses espèces d'abeilles sans aiguillon

Eine wissenschaftliche Notiz zu Haptoncus luteolus (Coleoptera: Nitidulidae) als Nestparasit von stachellosen Bienen

\section{REFERENCES}

Atkinson, E.B., Ellis, J.D. (2011a) Honey bee, Apis mellifera L., confinement behaviour toward beetle invaders. Insectes Soc. 58(4), 405-503 
Atkinson, E.B., Ellis, J.D. (2011b) Adaptive behaviour of honeybees (Apis mellifera) toward beetle invaders exhibiting various levels of colony integration. Physiol. Entomol. 36(3), 282-289

Audisio, P., Capolupo, P., Parisella, R., Santorelli, S. (1990) Nitidulidae (Coleoptera) - Rhizopus association: probable scourge of fruit crops in the year '90. Inf. Agrar. 46(21), 6971

Ellis, J.D., Delaplane, K.S., Cline, A.R., McHugh, J.V. (2008) The association of multiple sap beetle species (Coleoptera: Nitidulidae) with western honey bee (Apis mellifera) colonies in North America. J. Apic. Res. Bee World 47 (3), 188-189

Gillogly, L.R. (1982) New species and a key to the genus Haptoncus (Coleoptera: Nitidulidae). Pac. insects 24, 281291

Greco, M.K., Hoffmann, D., Dollin, A., Duncan, M., Spooner-Hart, R., Neumann, P. (2010) The alternative Pharaoh approach: stingless bees mummify beetle parasites alive. Naturwissenschaften 97, 319-323

Haddad, N., Esser, J., Neumann, P. (2008) Association of Cryptophagus hexagonalis (Coleoptera: Cryptophagidae) with honey bee colonies (Apis mellifera). J. Apic. Res. 47, 189-190

Halcroft, M., Spooner-Hart, R., Neumann, P. (2011) Behavioural defence strategies of the stingless bee, Austroplebeia australis, against the small hive beetle, Aethina tumida. Insect. Soc 58, 245-253

Michener, C.D. (2013) Chapter 1-The Meliponini. In: Vit, P., Pedro, S.R.M., Roubic, D.W. (eds.) Pot-Honey: A Legacy of Stingless Bees, p. 12pp. Springer Science+Business Media, New York

Neumann, P., Elzen, J.D. (2004) The biology of the small hive beetle (Aethina tumida, Coleoptera: Nitidulidae): Gaps in our knowledge of an invasive species. Apidologie 35(3), 229-248

Neumann, P., Ritter, W. (2004) A scientific note on the association of Cychramus luteus (Coleoptera: Nitidulidae) with honeybee (Apis mellifera) colonies. Apidologie 35, 665-666

Neumann, P., Evans, J., Pettis, J.S., Pirk, C.W.W., Schäfer, M.O., Tanner, G., Ellis, J.D. (2013) Standard methods for small hive beetle research. In: Dietemann, V., Ellis, J.D., Neumann, P. (eds.) The COLOSS BEEBOOK. Volume II: standard methods for Apis mellifera pest and pathogen research. J. Apic. Res, vol. 52, pp. 1-32

Spiewok, S., Neumann, P. (2006) Infestation of commercial bumblebee (Bombus impatiens) field colonies by small hive beetles (Aethina tumida). Ecol. Entomol. 31, 623-628

Yunus, A., Ho, T.H. (1980) List of Economic Pests, Host Plants, Parasites and Predators in West Malaysia [1920-1978], p. 538. Ministry of Agriculture of Malaysia, Kuala Lumpur 